\title{
Group B Streptococcus detection: comparison of PCR assay and culture as a screening method for pregnant women
}

\begin{abstract}
Streptococcus agalactiae or group B Streptococcus (GBS) is one of the most important causal agents of serious neonatal infections. Numerous assays have been evaluated for GBS screening in order to validate a fast and efficient method. The aim of this study was to compare the culture technique (established as the gold standard) with the molecular method of polymerase chain reaction (PCR) with specific primers (atr gene). Two hundred and sixty-three samples were analyzed. Vaginal samples were collected, according to the Centers for Disease Control and Prevention (CDC) recommendations, from women over 35 weeks of pregnancy at Hospital de Clínicas de Porto Alegre (HCPA). Two different extraction methods were tested in all samples collected. PCR technique yielded 71 (26.99\%) positive results. Sensitivity and specificity for PCR were $100 \%$ and $86.88 \%$, respectively. PCR demonstrated a shorter turnaround time than the culture. The molecular methodology proved to be a useful screening for GBS, allowing effective treatment to be initiated in shorter time to prevent newborn infection.
\end{abstract}

Keywords: Streptococcus agalactiae; polymerase chain reaction; culture; pregnancy.

\section{INTRODUCTION}

Streptococcus agalactiae, or Lancefield group B Streptococcus (GBS), is one of the most important causal agent of serious infections and neonatal sepsis. ${ }^{1-3}$ As many as $40 \%$ of all pregnant women present rectal and/or vaginal GBS colonization. ${ }^{4}$ The incidence of neonatal GBS infection is 0.5 per 100 live births. Vertical transmission from mother to the neonate by either pathway accounts for up to $75 \%$ of cases of neonatal GBS colonization, and 1\% to $2 \%$ of these infants will develop early-onset GBS infection. ${ }^{5,6}$

Since 2002, the Centers for Disease Control and Prevention (CDC) recommend GBS screening for pregnant women by culturebased method. This approach is preferable, resulting in more effective prevention that risk-based chemoprophylaxis (previous CDC recommendation)..$^{7-9}$ The standard method for the diagnosis of GBS colonization consists of culturing combined vaginal and anal swab in a selective broth medium that inhibits the growth of non-GBS microorganisms. However, this method requires at least $48 \mathrm{~h}$ for fully
GBS identification. Moreover, negative culture results are observed in some women whose infants subsequently develop GBS infection..$^{10}$

An ideal screening test for GBS colonization is which could accurately identify pregnant women who carry the bacteria (even low-count bacteria carriers) and presenting a short turnaround time. Many techniques have been tested in order to validate a fast and efficient method of GBS screening to replace the culture. ${ }^{11-13}$ Nowadays, molecular biology based assays, such as PCR (polymerase chain reaction) tests, have become the focus of investigation of detection of GBS colonization in pregnant women. ${ }^{14,15}$ In these tests, samples preparation and amplification targets are decisive to performance assay. A good target for GBS amplification is the atr gene because it is well studied in this species. Moreover, the atr is an essential gene, which means that it has to be expressed/present in all cells of this species. The gene encodes a protein amino acid transporter gs0538 which is extremely specific to S. agalactiae species. Because it is a housekeeping gene, probability of mutations in atr is comparatively rather low. ${ }^{16,17}$
Authors

Fernanda de-Paris ${ }^{1}$

Alice Beatriz Mombach Pinheiro Machado ${ }^{1}$

Tailise Conte Gheno ${ }^{2}$ Bruna Maria Ascoli²

Kátia Ruschel Pilger de Oliveira $^{1}$

Afonso Luis Barth ${ }^{1,2}$

${ }^{1}$ Serviço de Patologia Clínica, Unidade de

Microbiologia e Biologia Molecular, Hospital de Clínicas de Porto Alegre, RS, Brazil

${ }^{2}$ Departamento de Análises, Faculdade de Farmácia,

Universidade Federal

do Rio Grande do Sul (UFRGS), RS, Brazil

Submitted on: $12 / 19 / 2010$ Approved on: 01/07/2011

Correspondence to: Fernanda de Paris

Unidade de Microbiologia e Biologia Molecular Serviço de Patologia Clínica

Hospital de Clínicas de Porto Alegre

Rua Ramiro Barcelos, 2350 90035-930

Porto Alegre, RS

Brazil

fparis@terra.com.br

Financial Support: Fundo de Incentivo à Pesquisa e Ensino, Hospital de Clínicas de Porto Alegre (FIPE/HCPA).

We declare no conflict of interest.

(C)2011 Elsevier Editora Ltda. All rights reserved. 
The aim of study was compare this atr gene PCR with the gold standard (culture-based method) to evaluate the PCR performance as GBS colonization screening in pregnant women. Additionally, we tested two different extraction methods to amplify atr gene: a commercial kit and thermal lysis protocol, searching more cost-effective molecular tests.

\section{MATERIALS AND METHODS}

\section{Samples}

Combined rectal/vaginal specimens were collected to conduct this study according to the CDC recommendations. ${ }^{10}$ Samples collected were sent to the laboratory for microbiology and molecular tests for group B Streptococcus identification. We analyzed 263 samples of women at 35 or more weeks of pregnancy, in labor or not, attending the emergency obstetric room at Hospital de Clínicas de Porto Alegre (HCPA) from September 2007 to September 2008.

\section{Microbiology tests}

The swabs were inoculated into Todd Hewitt (Himedia Laboratories, India) selective medium supplemented with gentamicin $(8 \mu \mathrm{g} / \mathrm{mL})$ and nalidixic acid $(15 \mu \mathrm{g} / \mathrm{mL})$. The selective medium was incubated at $36^{\circ} \mathrm{C}$ in $5 \% \mathrm{CO}_{2}$ for $18 \mathrm{~h}$, and then subcultured onto blood agar plates (BioMérieux, Marcy l'Étoile, France), which were incubated at $36^{\circ} \mathrm{C}$ in $5 \% \mathrm{CO}_{2}$ for $24 \mathrm{~h}$. After incubation the plates were inspected for $\beta$-hemolytic colonies. When no $\beta$-hemolytic colonies were observed after $24 \mathrm{~h}$, plates were reincubated for another $24 \mathrm{~h}$ and inspected again. The $\beta$-hemolytic colonies whose morphology was consistent with group B Streptococcus were subcultured in broth and submitted to the CAMP (Christie, Atkins, Munch, Petersen) test. The colonies positive for the CAMP test were presumptively considered GBS.

\section{Polymerase chain reaction (PCR)}

\section{Sample preparation and DNA extraction}

The swabs were incubated for 15 to $18 \mathrm{~h}$ into Todd Hewitt selective medium. After centrifugation of broth, the precipitate was washed with 1X PBS solution and resuspended in TE buffer (10 mM Tris-HCl, 0.1 mM EDTA, pH 7.5). This solution was submitted to two different DNA extraction protocols: thermal lysis and thermal lysis followed by silica DNA extraction by commercial kit.

The thermal lysis was performed using TE solution for $10 \mathrm{~min}$ at $100^{\circ} \mathrm{C}$ to lyse bacterial cell wall. ${ }^{18}$ The second DNA extraction protocol was performed using the commercial kit QIAmp (Qiagen, Valencia, USA), according to manufacturers instructions. This additional step in DNA extraction was conducted for ensuring the PCR inhibitors elimination.

\section{Polymerase chain reaction (PCR) gene atr}

For the PCR reaction we used the atr primers 5'CAA CGA TTC TCT CAG CTT TGT TAA-3' and 5'TAA GAA ATC TCT TGT GCG GAT TTC-3', producing a 780-bp fragment that is specific for the gene atr. ${ }^{19}$ The amplified PCR product of one clinical isolate was sequenced and the atr sequence obtained was compared in GenBank using the Basic Local Alignment Search Tool (BLAST) of National Center for Biotechnology Information, Bethesda, MD (http://www.ncbi.nlm. nih.gov/BLAST/). This isolate sample was used as a positive control in all PCR reactions.

The volume of reaction was $25 \mu \mathrm{L}$ and was prepared as follows: $67 \mathrm{mM}$ Tris- $\mathrm{HCl}, 16 \mathrm{mM}(\mathrm{NH} 4)_{2} \mathrm{SO}_{4}$, $0.01 \%(\mathrm{w} / \mathrm{w})$ Tween-20 ( $\mathrm{pH} 8.8$ at $\left.25^{\circ} \mathrm{C}\right), 1.5 \mathrm{mM} \mathrm{MgCl}_{2}$, $0.25 \mathrm{mM}$ dNTP (ABgene ${ }^{\circledR}$, Epson, UK), $0.4 \mathrm{mM}$ of each primer, $1.25 \mathrm{U}$ of enzyme Super-Term DNA polymerase (JMR Holdings, London, UK) and $5 \mu \mathrm{L}$ of each DNA sample. The amplification was performed with an initial denaturation at $94^{\circ} \mathrm{C}$ for $1 \mathrm{~min}$ followed by 30 cycles of $1 \mathrm{~min}$ at $94^{\circ} \mathrm{C}, 45 \mathrm{~s}$ at $55^{\circ} \mathrm{C}$ for primer annealing, $1 \mathrm{~min}$ at $72^{\circ} \mathrm{C}$ for elongation and a final period of extension at $72^{\circ} \mathrm{C}$ for $10 \mathrm{~min}$.

The amplification products were detected by electrophoresis using $10 \mu \mathrm{L}$ of the amplified reaction mixture in agarose gel $2 \%$, containing $0.4 \mathrm{mg} / \mathrm{mL}$ ethidium bromide. Visualization was performed with ultraviolet light transilluminator. A 100 -bp molecular weight marker (Invitrogen ${ }^{\circledR}$, Calbad, USA) and a positive control of $S$. agalactiae were used to evaluate the PCR products. The samples presenting a 780-bp amplicon were considered positive for GBS.

\section{Statistical analysis}

Sensitivity, specificity, PPV and NPV were calculated for the PCR technique using culture as gold standard. The concordance between assays was determined using the Kappa coefficient. The statistical analysis was performed in SPSS $^{\circledR}$ version 14.0.

\section{RESULTS}

In the molecular method, all samples were tested with both DNA extractions (thermal lysis only and thermal lysis + Qiagen extraction) before PCR reaction. We observed four discrepancies $(4 / 263)$ between the two methods. PCR reactions with and without Qiagen extractions were compared, yielding a Kappa of 0.961, which indicates excellent agreement. ${ }^{20}$ Thus, the PCR method was used inrespective of the process of DNA extraction used.

Altogether, the culture method turned out positive in $42(15.96 \%)$ samples, while the PCR technique was 
Table 1. Comparison of PCR and Todd Hewitt culture medium results

\begin{tabular}{lccc}
\hline \multirow{2}{*}{ PCR } & \multicolumn{2}{c}{ Culture } & Total \\
& Positive & Negative & \\
\hline Positive & 42 & 29 & 71 \\
\hline Negative & 0 & 192 & 192 \\
\hline Total & 42 & 221 & 263 \\
\hline
\end{tabular}

positive in $71(26.99 \%)$ (Table 1$)$. All culture-positive samples were also positive with the PCR technique, therefore resulting in 100\% PCR sensitivity (95\% CI: 91.62-100). Of the 221 culture-negative samples for GBS, 29 were positive with PCR and 192 were negative with both methods, which indicate a specificity of 82.6\% (95\% CI: 81.79-90.71) of the molecular method. The negative predictive value was $100 \%$ and positive predictive value was $59 \%$ (Figure 1). The agreement beyond chance (Kappa) between the techniques was 0.68 , indicating substantial agreement. ${ }^{20}$

\section{DISCUSSION}

Despite CDC recommendations to use culture as GBS screening in pregnant women, many routine clinical situations require a faster and more efficient method than culture. ${ }^{11-13}$ Therefore, this study reports results for two different extraction protocols and the use of atr gene as amplification target by PCR and its potential use as GBS screening test. Thermal lysis is the cheapest extraction method and has good performance for this samples when compared to the Qiagen kit. This extraction protocol could present the best cost-effectiveness ratio when applied in clinical laboratory routine.

GBS colonization rates were $15.96 \%$ using the culture and $26.99 \%$ using PCR. In Brazil, the GBS colonization rate was estimated by Borger and co-workers to be between $15 \%$ to $25 \%$. However, the prevalence of GBS colonization could vary widely with geographic location, age, parity and socio-economic status. ${ }^{21}$ Furthermore, a review conducted in 1998 on the prevalence of colonization by GBS in developing countries suggested that colonization rates may be underestimated in many studies due to inadequate culture techniques employed..$^{22}$ Recent Brazilian studies using PCR to detect GBS have reported 21.6\%

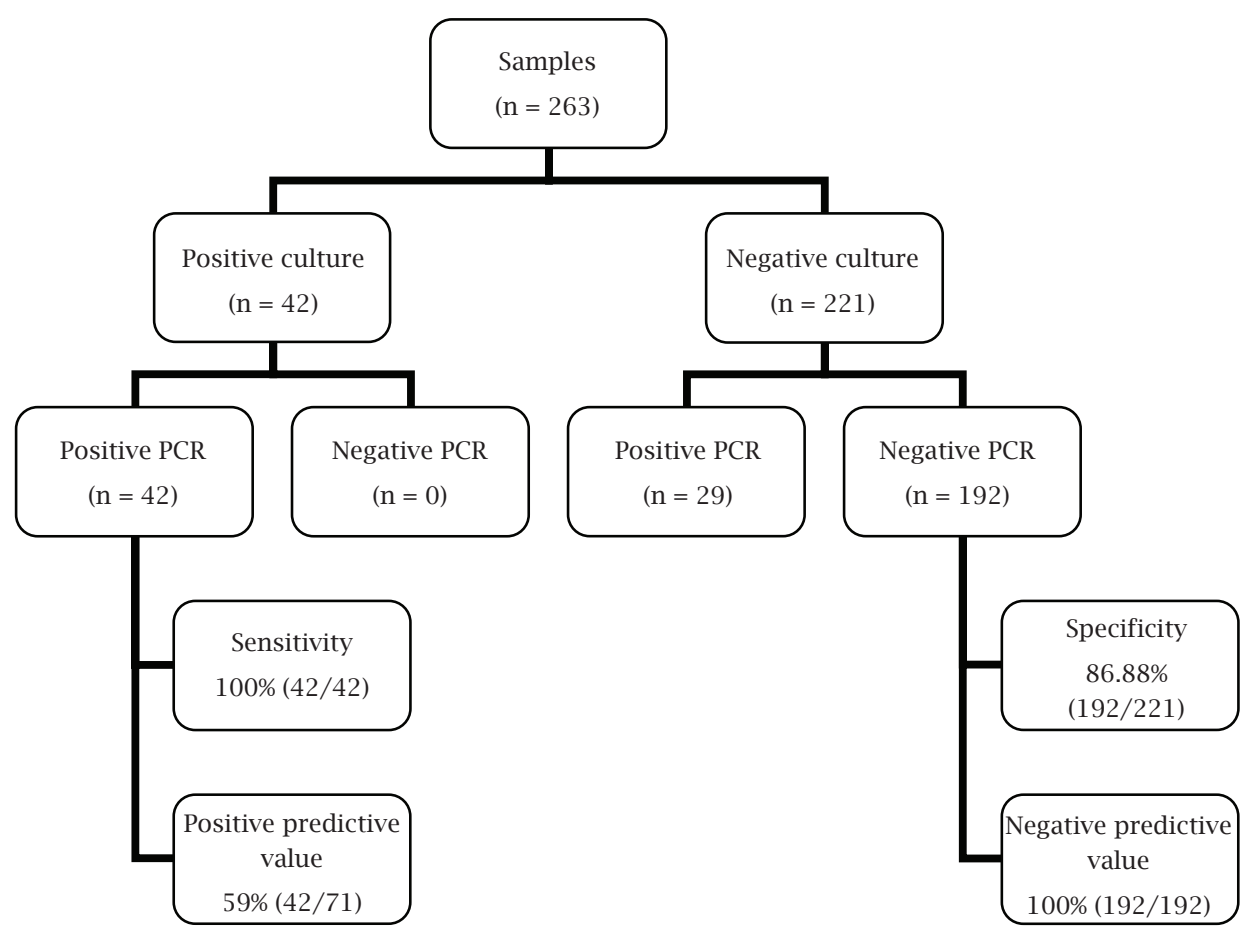

Figure 1: Diagram of sensitivity, specificity and predictive values of identifying the GBS presence in pregnant women by PCR assay. 
and $20.4 \%$ as colonization rates. ${ }^{7,21}$ These rates are very similar to those observed in this study.

Great sensitivity, high negative predictive value and rapid results are desirable parameters of a screening test. In our study, the sensitivity of PCR was $100 \%$, higher than the value observed in similar studies conducted by Gavino \& Wang ${ }^{15}$ and $\mathrm{Alfa}^{23}$, where the sensitivity was $95.8 \%$ and $90.5 \%$, respectively. Probably, the high sensibility is due to use of selective and enriched broth previous to performing the PCR. The negative predictive value was $100 \%$. This finding is important because it indicates that all samples with negative results are truly negative, which affords to safely withhold treatment from women presenting PCR negative samples. This is so important in clinical routine because false negative results in a screening test may lead to serious consequences for the patient, considering that this test is used to take a decision about antibiotic prophylaxis.

The specificity found was $86.88 \%$, greater than the $64.5 \%$ found by Gavino \& Wang. ${ }^{15}$ However, even being considered the gold standard, culture results can be false negative. It is known that culture may not be absolutely effective in the detection of GBS, since other bacteria of the vaginal/genital tract can inhibit the growth of GBS even when using the selective broth. So, the supposedly false positive results in PCR may actually indicate the presence of GBS in the studied material, since this is an analytical technique whose sensitivity could be greater than the bacteriological examination. The gold standard performance affects the positive predictive value parameter. Consequently, in our study the positive predictive value was $59 \%$.

Moreover, the culture is a time-consuming method requiring at least $48 \mathrm{~h}$ for fully GBS identification. The PCR proposed in this study, even using a previous incubation in selective broth, requires $24 \mathrm{~h}$ to give the final result. Therefore, GBS PCR has a considerable shorter turnaround time than the culture.

In summary, since the publication of the Guidelines of GBS colonization by the CDC in 2002, the incidence of neonatal infections decreased by more than $60 \%$. The use of new techniques with higher accuracy and faster results for detection of this microorganism could contribute even further to this improvement. ${ }^{2}$ Accordingly, our study indicates that the PCR technique has proven to have high sensitivity, and that it should be a useful screening method. Such methodology can be a diagnostic tool for GBS, allowing effective treatment and decreasing newborn morbidity and mortality. In this scenario, cost-effectiveness studies are necessary to assess the feasibility of implementing this method as a routine in centers with maternity wards.

\section{ACKNOWLEDGEMENTS}

This work was supported by Fundo de Incentivo à Pesquisa e Ensino, Hospital de Clínicas de Porto Alegre (FIPE/HCPA),
Fundação de Amparo à Pesquisa do Estado do Rio Grande do Sul (FAPERGS) and Conselho Nacional de Desenvolvimento Científico e Tecnológico (CNPq).

\section{REFERENCES}

1. Schuchat A. Epidemiology of group B stretococcal disease in the United States: shifting paradigms. Clin Microbiol Rev 1998; 11:497-513.

2. Schrag SJ, Zell ER, Lynfield R et al. A population-based comparison of strategies to prevent early-onset group B streptococcal disease in neonates. N Engl J Med 2002; 347:233-9.

3. Freitas F, Martins-Costa SH, Ramos JGL, Magalhães JA. Rotinas em Obstetrícia 5.ed. Porto Alegre, BR: Artmed, 2006.

4. Regan JA, Klebanoff MA, Nugent RP. The epidemiology of group B streptococcal colonization in pregnancy. Vaginal Infections and Prematurity Study Group Obstet Gynecol 1991; 77:604-10.

5. Winn HN. Group B Streptococcus infection in pregnancy. Clin Perinatol 2007; 34:387-92.

6. Edwards RK, Novak-Weekley SM, Koty PP et al. Rapid Group B streptococci screening using a Real-Time Polymerase Chain Reaction Assay. Obstet Gynecol 2008; 111:1335-41.

7. Costa AL, Lamy Filho F, Chein MB et al. Prevalence of colonization by group B Streptococcus in pregnant women from a public maternity of Northwest region of Brazil. Rev Bras Ginecol Obstet 2008; 30:274-80.

8. Schrag SJ, Zywicki S, Farley MM et al. Group B streptococcal disease in the era of intrapartum antibiotic profilaxis. N Engl J Med 2000; 342:15-20.

9. Bergeron MG, Ke D, Ménard C et al. Rapid detection of group B streptococci in pregnant women at delivery. N Engl J Med 2000; 343:175-9.

10. Schrag S, Gorwitz R, Fultz-Butts K, Schuchat A. Prevention of perinatal group $\mathrm{B}$ streptococcal disease. Revised guidelines from CDC. MMWR Recomm Rep 2002; 51:1-22.

11. Aziz N, Baron EJ, DSouza $\mathrm{H}$ et al. Comparison of rapid intrapartum screening methods for group B streptococcal vaginal colonization. J Matern Fetal Neonatal Med 2005; 18:225-9.

12. Carroll KC, Ballou D, Varner M et al. Rapid detection of group B streptococcal colonization of the genital tract by a commercial optical immunoassay. Eur J Clin Microbiol Infect Dis 1996; 15:206-10.

13. Park $\mathrm{CH}$, Ruprai D, Vandel NM et al. Rapid detection of group B streptococcal antigen from vaginal specimens using a new Optical Immuno Assay technique. Diagn Microbiol Infect Dis 1996; 24:125-8.

14. Wang E, Richardson $\mathrm{H}$. A rapid method for detection of group B streptococcal colonization: testing at the bedside. Obstet Gynecol 1990; 76:882-5.

15. Gavino M, Wang E. A comparison of a new rapid real-time polymerase chain reaction system to traditional culture in determining group B Streptococcus colonization. Am J Obstet Gynecol 2007; 197:388e1-388e4.

16. Glaser P, Rusniok C, Buchrieser C et al. Genome sequence of Streptococcus agalactiae, a pathogen causing invasive neonatal disease. Mol Microbiol 2002; 45:1499-513.

17. Elbaradie SM, Mahmoud M, Farid M. Maternal and neonatal screening for Group B streptococci by SCP B gene based PCR: a preliminary study. Ind J Med Microbiol 2009; 27:17-21. 
18. York MK, Gibbs L, Chehab F, Brooks GF. Comparison of PCR detection of mecA with standard susceptibility testing methods to determine methicillin resistance in coagulasenegative staphylococci. J Clin Microbiol 1996; 34:249-53.

19. Jones N, Bohnsack JF, Takahashi S et al. Multilocus sequence typing system for group B Streptococcus. J Clin Microbiol 2003; 41:2530-6.

20. Fleiss AR. Clinical epidemiology. In: The arquitecture of clinical research. Philadelphia, Saunders, 1985.
21. Borger IL, Doliveira REC, Castro ACD, Mondino SSB. Streptococcus agalactiae in pregnant women: prevalence of colonization and antimicrobial susceptibility evaluation. Rev Bras Gineco Obstet 2005; 27:575-9.

22. Stoll BJ, Schuchat A. Maternal carriage of group B streptococci in developing countries. Pediatr Infect Dis J 1998; 17:499-503.

23. Alfa MJ, Sepehri S, Gagne PD et al. Real-time PCR assay provides realiable assessment of intrapartum carriage of group B Streptococcus. J Clin Microbiol 2010; 48:3095-9. 